\title{
SOME FACTORS AFFECTING ARTIFICIAL CURING OF ONION BULBS AND ITS EFFECTS ON THE STORABILITY
}

\author{
*ABD-EL RAHMAN, M. M. ～* EBEAID, M. T
}

\begin{abstract}
This research aimed to study some factors affecting the artificial curing of onion bulbs and its effects on the storability of bulbs in terms of (total soluble solids TSS and onion storage losses) comparing with the conventional curing method in Egypt. The study also aimed to determine the influence of different levels of maturity stages (harvesting time), about of 20,30, 40\% and $50 \%$ tops down and bulb sizes (large, medium and small) on the change in the bulbs moisture content and the time required for complete curing.

The obtained results showed that, during field curing, the bulbs moisture content decreased gradually from initial moisture of $87-90 \% \pm 0.5 \%$ (w.b) to a final level of $81.5 \% \pm 0.5 \%$ (w.b) after 16 day (384 h). At maturity stages of $20,30,40$, and $50 \%$ of tops down, the results revealed that, curing of onion bulbs artificially can reduce the required time of curing by about $68.8,71.9,75$ and $81.3 \%$ for large size of bulbs, and by 71.9 , 75,78 and 81.3 for medium and small size of bulbs, compared with traditional curing method of bulbs (control treatment). The results also showed that artificial curing of bulbs at 20,30,40, and 50\% of tops down, may save the time required for curing bulbs comparing to traditional curing method of onion bulbs, that in turn increase the available time for preparing the land of the next crop (maize, rice and cotton crops; and other summer vegetable crops) by about $13,13.5,14$ and 15 day when curing large size of bulbs, while it save about 13.5, 14, 14.5 and 15 day when curing medium and small size of bulbs. The storability of onion bulbs improved with about of $12.73 \%$ for bulbs harvested at 40 and $50 \%$ tops down, while it was $12.44 \%$ for bulbs harvested at $30 \%$ tops down comparing with traditional curing.
\end{abstract}

* Senior Researcher, Agric. Eng. Res. Inst. (AEnRI), Giza. 


\section{INTRODUCTION}

$\mathrm{P}$ ostharvest losses of food after, especially for perishable crops, and in developing countries are very high. The three main objectives of applying postharvest technology to harvested fruits and vegetables are to maintain quality (appearance, texture, flavor and nutritive value), to protect food safety, and to reduce losses between harvest and consumption. Effective management during the postharvest period, rather than the level of sophistication of any given technology, is the key in reaching the desired objectives.

Onion (Allium cepa L.) is one of the most important field crops widely grown in Egypt, and it has a very high potential for exportation. In Egypt, the cultivated area of onion crop is 18061 feddans, which annually produces over 252166 tones yearly (Ministry of Agriculture and Land Reclamation, 2008). Onion bulbs are always harvested at complete mature stage with green topping leaves and high moisture content. Increasing productivity of onion with high quality is an important target by the onion growers. One of the major problems facing exportation of Egyptian onion is the lower storability characteristics when shipping to the European countries that exposing the bulbs to decay and hence facing rejection from the exporter.

Sanguansri and Gould (1992) showed that a pilot onion curing plant using forced heated air was assembled and tested as an alternative to field curing. The bulbs from the curing plant were placed in storage and tested for weight loss, firmness and color. Results showed that cured onions had lower weight loss and more enhanced color.

Kader (1992) showed that some products are cured (onions, garlic's, sweet potatoes, and new crop potatoes) after harvesting and before storage or marketing. Onions and garlic's are cured to dry the necks and outer scales. Curing helps heal harvesting injuries, reduces water loss, and prevents entry of decay causing organisms during storage. Curing may be done in the field, in curing rooms, or during transit. The treatment was most effective if the crop was removed from the field for drying within 48 $\mathrm{h}$ of topping, thus avoiding severe infection of the damaged green neck tissue.

Pandey et al. (1993) subjected dark red onions for various combinations 
of post harvest treatments prior to storage (foliage removal at harvest or no foliage removal, curing in sun or a solar drier or no curing, foliage removal before or after curing). They found that percentage of total loss was highest in bulbs with foliage removed at harvest and cured in sun before storage $(67.16 \%)$, and lowest in bulbs cured in sun with foliage attached and stored with dry foliage (56.35\%) while bulbs cured in sun with foliage attached but with dry foliage removed prior to storage (61.18 $\%)$.

Wilson and Estes, (1994) showed that the air heated by gas or other types of heaters will dry onions satisfactorily in 48 to 72 hours, depending upon the condition of the onions and the atmospheric conditions. They stated that fans should be sized to provide from 3 to 5 cubic feet of air per minute per bushel of onions ( 2 to $3.35 \mathrm{~m}^{3} / \mathrm{min}$. ton) of onions. Air heated to $37.8{ }^{\circ} \mathrm{C}$ is sufficient for rapid drying. They also stated that air temperatures above $43.3{ }^{\circ} \mathrm{C}$ will damage the bulbs. A reduction of 5 to 8 $\%$ in the bulb weight is usual during artificial curing.

Maw et al. (1997a and 1997b) reported that onions harvested at optimum maturity, need to $48 \mathrm{~h}$ to obtain a good level of curing. They noticed that a small benefit was observed when curing was extended to $72 \mathrm{~h}$. For late harvested onions, $24 \mathrm{~h}$ curing was sufficient.

Yang and Lee (2000) studied the effect of postharvest curing on respiration and quality of onion bulbs during cold storage. They found that non-curing samples showed rapid increase of carbon dioxide production after 50 day of storage. They stated that this increase might be related to the incidence of fungal decay. They found that ncidence of decay was significantly reduced by additional drying. Yang and Lee also stated that one of the beneficial effects as curing onion bulbs for 3 month at $25 \mathrm{C}^{\circ}$ was keeping the bulbs at low moisture contents, which in turn resulted in reducing the decay.

Bahnasawy (2000) concluded that a reduction of $4 \%$ in the onion weight was found during curing process. Field curing is the least expensive of all curing methods but it recorded the highest percentage of losses during storage as well as the highest sprouting percentage.

ARC (2003) declared that in Egypt, most onion is harvested when the bulbs are well mature. Harvest occurs after the tops have fallen (50\%) and 
are very dry. The common practice to reduce the moisture content of bulbs is to leave the onion crop in windrows for a few days (2-3 weeks) depending upon the circumstances of bulbs and the weather conditions. This conventional method is a satisfactory procedure if the weather is dry and the relative humidity is low during field curing process.

Abd El-Rahman, (2004) concluded that blowing heated air at $40{ }^{\circ} \mathrm{C}$ and $3.35 \mathrm{~m}^{3} / \mathrm{min}$.ton for a period of $72 \mathrm{~h}$ provides satisfactory curing which was associated with the highest storability of bulbs. The obtained results showed that the total loss in onion weight was $(11.8 \%)$ and the value of TSS was $(17.48 \%)$, with the dry matter percentage of $(19.56 \%)$.

Lisa and Kader (2004) declared that curing root and tuber crops such as sweet potatoes, potatoes, cassava and yarns is an important practice if these crops are to be stored for any length of time. Curing is accomplished by holding the produce at high temperature and high relative humidity for several days while harvesting wounds heal and a new, protective layer of cells form. Several methods of artificial curing have been tried, but the method most commonly used for onions and garlic's bulbs involves blowing heated air at 35 to $45{ }^{\circ} \mathrm{C}$ (95 to $113 \mathrm{~F}$ ) vertically through a grill on which the bulbs placed in mesh bags. Such treatment continued for a period of 8 to $12 \mathrm{hr}$ usually provides satisfactory curing for either immediate shipment to market or storage for later sale.

Grahame (2005) and Marita (2006) showed that curing bulbs is the process by which the outer leaf sheaths and neck tissues of the bulb are dried. Warm temperatures, low relative humidity, and good airflow are conditions needed for efficient curing. They added that curing is essential to obtain maximize storage life and have minimal decay.

Boyette et. al (2008) illustrate that to maximize yield and quality, onions and garlic's bulbs should be harvested only when mature. The bulbing phase is often very rapid and occurs near the end of the onion's active growth period. During this time, the bulbs tops will begin to fall over and die. Onions should be ready to harvest when approximately 10 to 20 percent of the tops have fallen over.

The reduction of postharvest losses (preserving nutritional value, maintaining quality, and reducing safety risks) is of great importance. 
Several treatments and techniques are available (either used or can be used). Long storage of onion bulbs is a problem particularly during spring and summer month. Fungi attack onion bulbs during the growing season, harvesting, storage and marketing causing annual crop losses.

- The general objective of this research work was to study some factors affecting postharvest curing of onions bulbs artificially and its effect on the storability of onion bulbs in terms of total soluble solids TSS and onion storage losses, comparing with the conventional curing method in Egypt.

- The specific objectives were to determine the influence of different maturity stages (harvesting time) and bulb sizes on the change in the bulbs moisture content and the time required for complete curing.

\section{MATERIALS AND METHODS}

To fulfill the objective of this study, a flatbed batch dryer type that was constructed tested at the workshop of Ag. Eng. Res. Inst. (AEnRI), ARC, (Abd El-Rahman, 2004) was used for the work of this paper.

\section{- Materials.}

The experiments were carried out in the experimental farm of ELbaramon Research Station, Dakahlia Governorate, during 2008 onion harvesting season, using a local cultivar of onion bulbs (Giza - 20). This variety is prevalence grown in Dakahlia Governorate and characterized by its marked pungency, high dry matter content, firm and tight outer scales, and closed neck which enable it a longer storage period.

\section{- Structure of the dryer.}

The gross dimensions of the dryer are $125 \mathrm{~cm}$ long, $75 \mathrm{~cm}$ wide and 80 $\mathrm{cm}$ high, as shown in Fig (1).

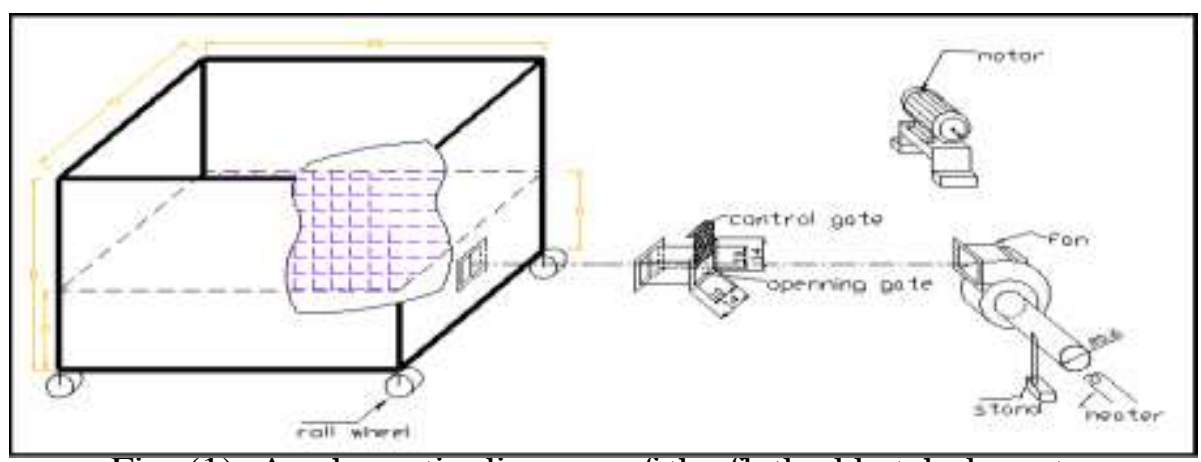

Fig. (1): A schematic diagram of the flatbed batch dryer type. 
The onion bulbs were placed on a mesh wire floor above the plenum. Mesh wire was installed $30 \mathrm{~cm}$ above the bottom of the batch forming an air chamber under the wire netted floor. The storage volume above the floor was $0.47 \mathrm{~m}^{3}$. A blower and duct for forcing heated air are located at one side of the dryer house, to force the drying air from the plenum through the bulbs. Electric heaters $(4 \mathrm{~kW})$ were fixed in open steel cylinder of $10 \mathrm{~cm}$ diameter and connected to a dial thermostat to adjust the drying air temperature The blower was powered by a single phase electric motor of $0.375 \mathrm{~kW}$ and $2850 \mathrm{rpm}$.

\section{- Experimental Treatments.}

-The main variables taken in this evaluation stage were selected according to the relevant studies on the artificial drying (curing) of onions and as recommended by (Abd El-Rahman, 2004), as follows:

- Four different levels of maturity stages (harvesting times) about of 20, 30 and 40 and $50 \%$ of tops fallen down.

- Three different levels of bulb sizes (Large, Medium and Small).

\section{- Experimental Procedure:}

Onions bulbs variety Giza-20 was harvested manually when 20, 30, 40\% and $50 \%$ of the tops were fall down, at moisture content (MC) ranging from 87 to $90 \% \pm 0.5 \%$ w.b. After harvesting, bulbs were inspected for damage and graded into three sizes, according to the quality standard for fresh fruits and vegetables (Ministry of Economics and Foreign Trade, 1992) as follow: Size 1 (Large) $>6.0 \mathrm{~cm}$ in diameter; Size 2 (Medium) $4.5-6.0 \mathrm{~cm}$ in diameter and Size 3 (Small) $<4.5 \mathrm{~cm}$ in diameter.

Each sample were divided into two parts which devoted to field and artificial curing till the bulb (MC) reached to approximately $(81.5 \pm 0.5 \%$ w.b). Onions in this case, has a complete drying of roots, foliage, and the neck of the bulb and several layers of skin on the bulb.

- The first part of bulbs was subjected to curing in the open field. They were windrowed in one layer in the field, and covered by a layer of foliage (tops) and rice straw for 3 weeks under the ambient conditions as it usually practiced by Egyptian farmers.

- The second part of bulbs was taken periodically after damaged inspection, and manually placed on the netting wire floor in the dryer. Then the heated air passes from the bottom of dryer to diffuse up 
through the product with the heated air at $40{ }^{\circ} \mathrm{C}$ and air flow rate of 3.35 m3/min, as recommended by Abd El-Rahman (2004). Before starting on artificial curing, the dryer was operated with a dummy sample of bulbs for at least one hour. This period of time was essential for the heated air and the air flow rate to stabilize. After field and artificial curing, the samples were taken and placed in common burlap bags and kept under normal storage conditions (in a shaded and well ventilation area) for four months to determine the storability of the stored onion.

\section{- Measurements:}

\section{- Bulbs Moisture Contents:}

Moisture content of the onion was measured according to AOAC (1996). Onion samples were dried using drying oven at $105{ }^{\circ} \mathrm{C}$ until a constant weight. Samples were taken at intervals of four hours for artificial curing and daily for field curing to determine the moisture loss. Onion samples were weighed before and after drying.

\section{- Air Temperature:}

Copper-constantan thermocouples were used to measure the ambient air temperature at different points inside the dryer. They were calibrated at both boiling and freezing points. Thirty thermocouples (copperconstantan) were used and evenly distributed in three parallel planes (top, middle and bottom) in order to measure the ambient air temperature inside the dryer and one thermocouple to measure the ambient air temperature outside the dryer at intervals of 4 hours. The measurements were used a digital thermometer (model Omega-type J, USA).

\section{- Air Relative Humidity:}

A digital hygrometer, meter (model Fisher-77546, USA) was used to measure the relative humidity at adjacent points of temperature measurements.

\section{- Air Flow Rate:}

A hot wire anemometer model (testo 425, Germany) with accuracy reading $( \pm 0.01)$ was used to measure the inlet air speed at the dryer window in $\mathrm{m} / \mathrm{s}$. which multiplied by the calculated area of the intake window to give the required air flow rate in $\mathrm{m}^{3} / \mathrm{s}$ entering the dryer.

\section{- Solar Radiation Measurement:}

A monthly meteorological report (CLAC, ARC) of Dakhlia - Aga Station 
(May 2008) was used as a source of solar radiation data in $\mathrm{W} / \mathrm{m}^{2}$ during curing of onion bulbs in the open field.

\section{- Storability of Onions Bulbs:}

Onion bulbs storability in terms of total soluble solids (TSS) and total loss in weight of bulbs during a storage period was measured after harvesting and bulbs curing.

\section{- Total soluble solids (TSS).}

A hand held refractometer (model JENA-DDR 818466, USA) was used to measure the total soluble solids (TSS) for onion bulbs.

\section{- Total loss in weight of bulbs (\%).}

The percentage of total loss in weight of bulbs during a storage period of four months were determined by examining the yield every month, then rotting and sprouting bulbs were discarded and the remaining yield was weighed.

\section{RESULTS AND DISCUSSIONS}

\section{- Curing Times and Bulbs Moisture Contents.}

Under favorable climatic conditions, the bulbs are usually cured in the field. Curing is essential to obtain maximize storage life and have minimal decay.

The data showed that the hourly average solar radiation was $544 \mathrm{~W} / \mathrm{m}^{2} . \mathrm{h}$ during the experimental work. The data shows that the solar radiation was gradually increased from sunrise until reached a maximum value of 923.7 $\mathrm{W} / \mathrm{m}^{2} \mathrm{~h}$ at noon. It then decreased gradually until it a minimum value of $112.6 \mathrm{~W} / \mathrm{m}^{2} . \mathrm{h}$ at sunset. The variations in solar energy available during the curing time affected the ambient air temperature and air relative humidity in the field which in turn influenced on the average moisture loss and quality properties (storability) of onion bulbs. The daily average ambient air temperature and relative humidity during day light were 26.54 ${ }^{\circ} \mathrm{C}$ and $21 \%$, while, they were at night $21.42{ }^{\circ} \mathrm{C}$ and $44.83 \%$. This means that, the air relative humidity inversely related with ambient air temperature.

Figure (2) illustrates the changes in average bulbs moisture content as related to curing time for the traditional curing method. It also shows that, a gradual decrease in the bulbs moisture content from initial moisture of $87.24 \%$ to a final level of $81.72 \%$ after 16 day (384 h). It also reveals 
that the bulbs moisture content slightly decreases with a lower rate during the first four days and then starts to rapidly decrease during the next days, while it was remained nearly constant during the last three days at the end of curing period.

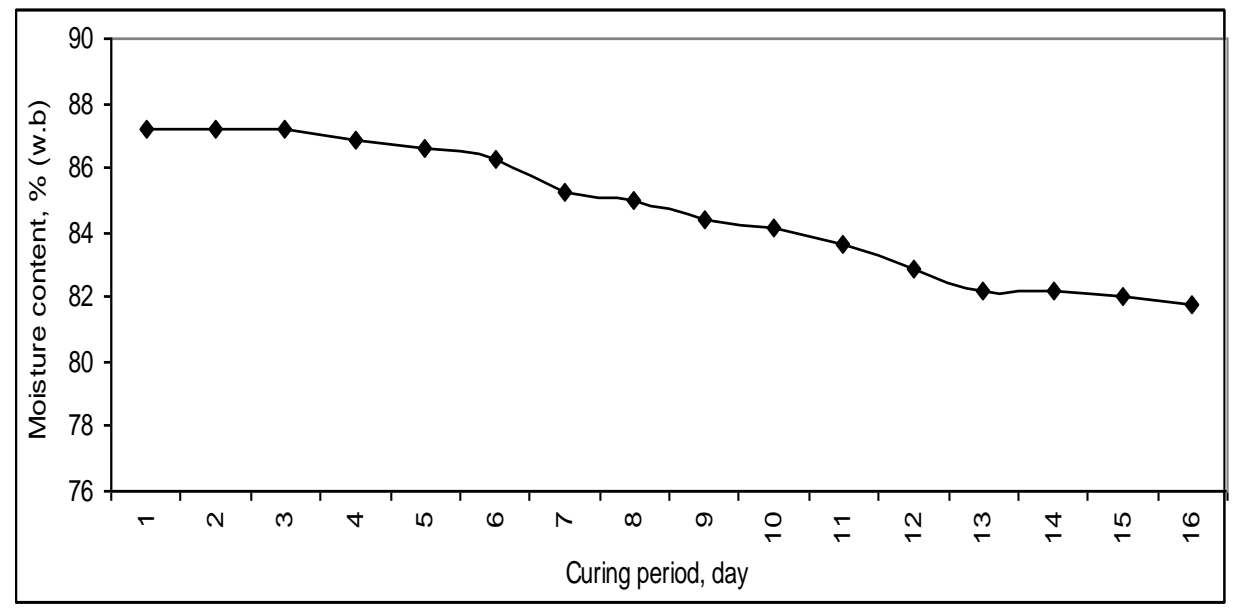

Fig. (2): Change in the average bulbs moisture content as related to curing period in the open field.

Figures (3) show the relationship between the percentages of bulbs moisture content and drying time under different harvesting time (maturity stage) and different bulb sizes. The curing process continued until the bulbs moisture content decreased to a level of $(81.5 \pm 0.5 \%$ w.b).

It can be seen from Fig. (3) that the curing period of bulbs decreased as the bulb size decreased from large to small bulbs, and decreased as harvest stage changed from 20 to $50 \%$ topes down.

Figure (3) shows that at $20 \%$ of topes down, increasing bulb sizes from small to large caused a gradual decrease in the bulbs moisture content from initial moisture of $89.23 \%$ to a final level of $81.7 \%$ in $120 \mathrm{~h}$ for large bulbs and $108 \mathrm{~h}$ for medium and small size of bulbs, respectively. Meanwhile, at harvest stage of 50\% tops down at the three bulb sizes caused an extreme decrease in the curing period to $72 \mathrm{~h}$ for all size of bulbs, as shown in Figure (3).

It can be observed that, curing bulbs artificially that harvested at a time of $20 \%$ topes down caused a gradual decrease in the bulbs moisture content from initial to a final moisture in $120 \mathrm{~h}$ for large bulbs (5 days) and $108 \mathrm{~h}$ 
(4.5 days) for medium and small size of bulbs. While at $30 \%$ tops down, this decrease reach to $108 \mathrm{~h}$ ( 4.5 days) for large bulbs, and $96 \mathrm{~h}$ (4 days) for medium and small size of bulbs. At all bulb sizes and at harvest stages (time of harvest) of 50\% topes down the results shows an extreme decrease in the curing period of $72 \mathrm{~h}$ (3 days), as shown in Figure (3).

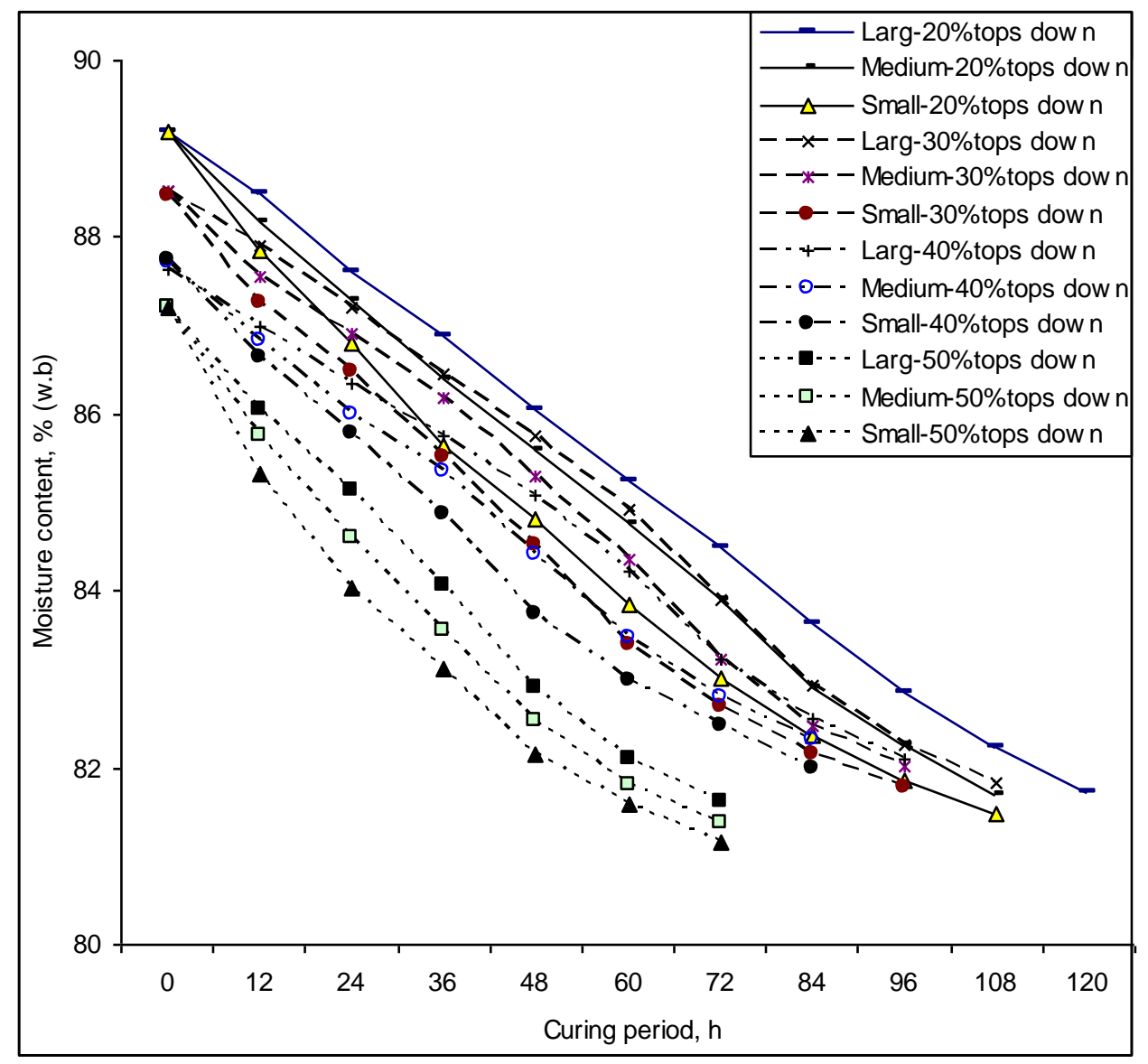

Fig. (3): The relationship between the bulbs moisture content and curing time as affected by different harvesting time (maturity stages) and different bulb sizes.

On other words, artificial curing of onion bulbs at different maturity stages $(20,30,40$, and $50 \%$ of tops down) can reduce the required time of curing onion by about $68.8,71.9,75$ and $81.3 \%$ for large size of bulbs and by $71.9,75,78$ and 81.3 for medium and small size of bulbs, respectively, compared with curing bulbs traditionally (control treatment). This means that, artificial curing of onion bulbs at 20,30, 40, and $50 \%$ of 
tops down, may save the time required for curing bulbs comparing to traditional curing method, that in turn increase the available time for preparing the land of the next crop (maize, rice and cotton crops; and other summer vegetable crops) by about 13, 13.5, 14 and 15 day when curing large size of bulbs, while it save about 13.5, 14, 14.5 and 15 day when curing medium and small size of bulbs.

\section{- The Storability of Onion Bulbs.}

The storability of onion bulbs in terms of total loss in weight of onions and total soluble solids (TSS) percentage is a good indicator of the curing process. Storability was measured during a storage period of 4 months after curing process of onions bulbs. Data collected on storability of onion bulbs as affected by different curing methods are presented in Table (1) and Figs (4) and (5).

It can be seen that, artificial curing of onion bulbs results in higher values of onion storability (total loss in weight of onions and total soluble solids TSS percentage) than that of the traditional curing expect at $20 \%$ tops down the storability were decreased comparing to control treatment, as shown in Figure (4) and (5). It was found also that total loss in weight of onions bulbs decreased (improvement) with about of $12.73 \%$ for bulbs harvested at 40 to $50 \%$ tops down, and it was $12.44 \%$ for bulbs harvested at $30 \%$ tops down comparing with traditional curing, as shown in Table (1). Whilst, a higher values of total loss in bulbs weight and lower values TSS was obtained when curing bulbs artificially at $20 \%$ of tops down comparing with traditional curing. Hence, these data should be excluded.

The recorded data revealed that during the artificial process at all harvesting stage of maturity from 30 , to 50\% tops down, the average weight of total loss during a storage period decreased and TSS increased comparing to field curing, as shown in Figs (4) and (5). On the other words, during artificial curing process, the quality that assessed as weight of total loss and TSS during a storage period was markedly deteriorated with decreasing maturity stages of $20 \%$ tops down at all size of bulbs comparing with other maturity stages from 30 to 50\% tops down. Although at any bulb sizes, the storability of onion bulbs was slightly improved with by harvesting at later stages of maturity (from 30 to 50\% 
tops down).

The results showed that, the maximum deteriorated of bulbs $(17.74 \%)$ was associated with minimum TSS (13.35\%) occurred at $20 \%$ tops down at large size of bulbs, comparing with the deteriorated value of the control treatment $(17.36 \%)$ and $(16.34 \%)$ for total loss and TSS, respectively. Hence, it should be excluded since it was found that the total losses of weight increase extremely and TSS decreased at this level of maturity stages. This increase in the total loss of bulbs at early stage of maturity (20\% tops fall down) may be due to the increase in bulbs moisture contents that may decrease the dry matter percentage.

Table (1): Total loss in weight of onion bulbs (\%) as affected by two types of curing methods.

\begin{tabular}{|c|c|c|c|c|c|c|}
\hline \multirow{2}{*}{$\begin{array}{c}\text { Curing } \\
\text { methods }\end{array}$} & \multirow{2}{*}{$\begin{array}{c}\text { Harvesting time } \\
\text { (tops down), }\end{array}$} & \multicolumn{3}{|c|}{ Bulb sizes } & \multirow{2}{*}{ Average } & $\begin{array}{c}\text { (\%) } \\
\text { Improve- } \\
\text { ment }\end{array}$ \\
\cline { 3 - 6 } & 20 & Large & Medium & Small & & -0.46 \\
\hline \multirow{3}{*}{$\begin{array}{c}\text { Artificial } \\
\text { curing }\end{array}$} & 30 & 17.74 & 17.64 & 17.44 & 17.44 & 12.44 \\
\cline { 2 - 7 } & 40 & 15.25 & 15.22 & 15.20 & 15.20 & 12.73 \\
\cline { 2 - 7 } & 50 & 15.12 & 15.15 & 15.15 & 15.15 & 12.73 \\
\hline $\begin{array}{l}\text { Traditional curing } \\
\text { (control treatment) }\end{array}$ & & & & 15.08 & 15.08 & \\
\hline
\end{tabular}

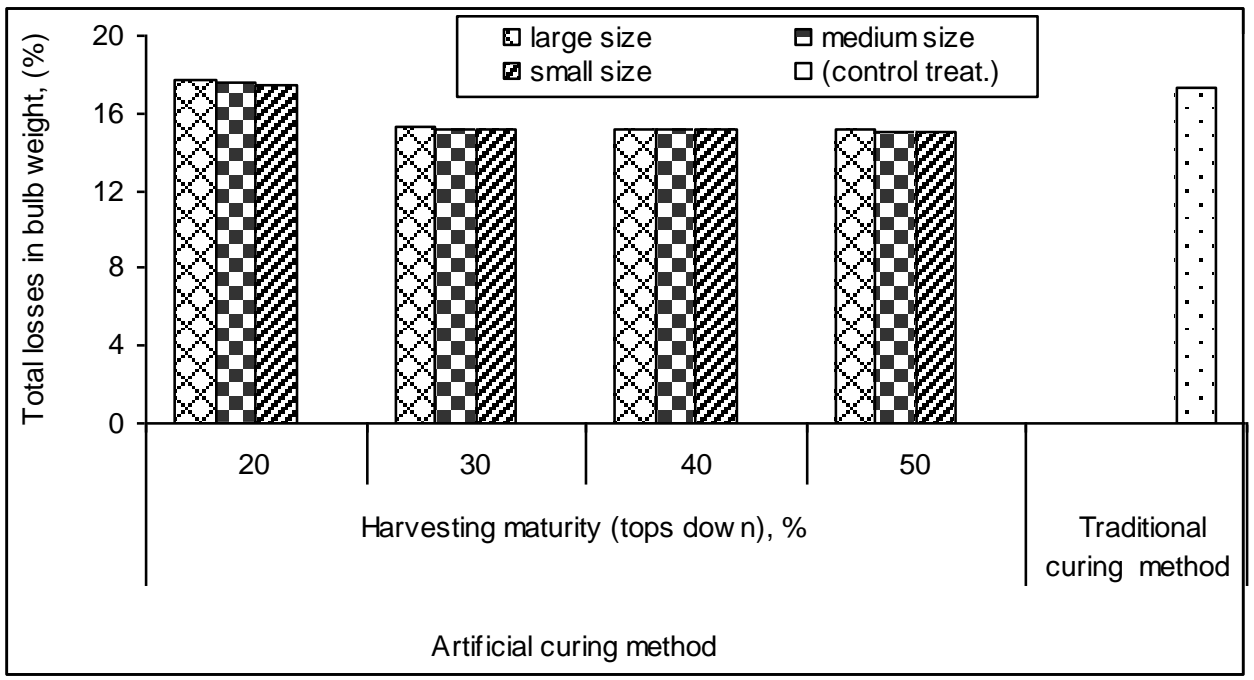

Fig. (4): The relationship between the bulbs storability (total loss in weight of bulbs) during storage period of 4 months as affected by different curing methods. 


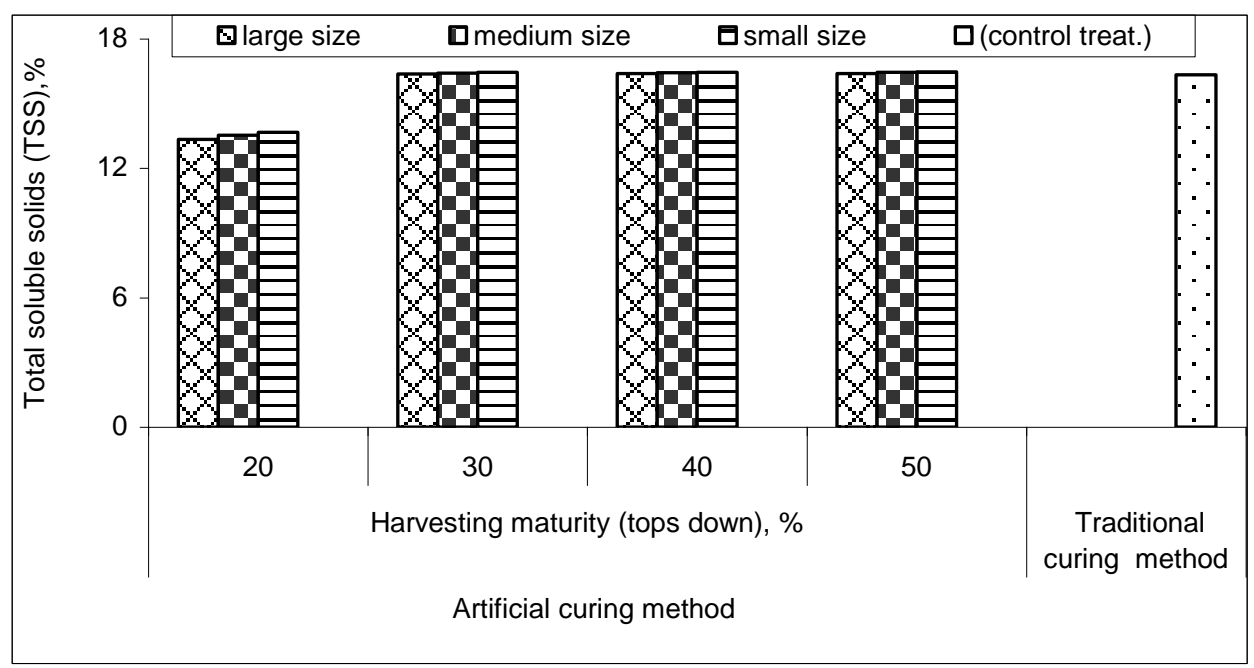

Fig. (5): The relationship between the bulbs TSS (total soluble solids) during storage period of 4 months as affected by different curing methods.

\section{SUMMARY AND CONCLUSION}

Based on the experimental results the following can be obtained:

- During field curing, the bulbs moisture content decreased gradually from initial moisture of $87-90 \% \pm 0.5 \%$ (w.b) to a final level of 81.5 $\pm 0.5 \%$ (w.b) after 16 day ( $384 \mathrm{~h}$ ). Meanwhile, adjusting the dryer to artificial curing of onion bulbs using $40{ }^{\circ} \mathrm{C}$ and air flow rates of 3.35 $\mathrm{m} 3 /$ min.t can reduce the required time of curing onion that harvested at maturity stages of 30,40 , and $50 \%$ of tops down, can reduce the required time of curing by about $71.9,75$ and $81.3 \%$ for large size of bulbs, and by 75,78 and $81.3 \%$ for medium and small size of bulbs, compared with traditional curing method of bulbs (control treatment).

- The saved time during artificial bulbs curing may be increase the needed time for preparing the land of the next crop (maize, rice and cotton crops; and other summer vegetable crops) by about 13, 13.5, 14 and 15 day when curing large size of bulbs, while it save about 12.5, 14, 14.5 and 15 day when curing medium and small size of bulbs.

- The quality that assessed as TSS and weight of total loss during a storage period was markedly deteriorated with decreasing maturity stages of $20 \%$ tops down at all size of bulbs comparing with other maturity stages from 30 to $50 \%$ tops down. On other words, storability 
of onion bulbs was slightly improved with increasing maturity stages from 30 to $50 \%$ tops down at any bulb sizes comparing to field curing. - At any bulb size, a little difference in the storability of bulbs was found during artificial curing at 30,40 and $50 \%$ tops down. While, the bulbs storability (total loss in weight of bulbs during a storage period) increased by decreasing the maturity stages to $20 \%$ tops down. The lowest storability of onion bulbs was always associated with highest value of average percentage of total loss in onion weight (17.74\%) and lowest value of TSS (13.35\%)which was recorded at the treatment including $20 \%$ tops down with large size of bulbs.

\section{REFERENCES}

Abd EL-Rahmman. M. M.(2004). Development and Evaluation of a Mobile Flatbed Batch Dryer for Artificial Curing of Bulb Onions. Misr. J. Agric. Eng., 21(2):185 -198

AOAC. (1996). Official methods of analysis, 16 th Ed. Aassociation of Official Analytical Chemists. Washington D. C.

ARC, Agricultural Research Center. (2003). Onion crop. National

Program of Onion Research. Ministry of Agricultural and Land Reclamation. No. (852).

Bahnasawy, A. H. (2000). Onion losses during storage as influenced by curing method. Misr J. Ag. Eng. 2001. Vol. 17 No (4): 209-225.

Boyette, M. D.; D. C. Sanders, and E. A. Estes (2008). Maintaining the quality of North Carolina Fresh Produce. North Carolina Cooperative Extension Service. North Carolina State Univ., USA.

Grahame D. (2005). Production Yearbookfor 1990. Horticultural marketing. Food and Agriculture Organization of the united nations, Rome.

Kader, A.A. (1992). Postharvest technology of horticultural crops. Publication 3311 University of California Division of agriculture and natural resources.

Lisa, K. and , A.A. Kader (2004). Postharvest horticultural series No. 8. Small-Scale Postharvest Handling Practices: A Manual for Horticultural Crops (4th Edition). University of California - Davis, California.

Marita C. (2006). Recommendations for Maintaining Postharvest 
Quality. Postharvest Technology Research Information Center. Department of Plant Sciences, University of California, Davis, CA 95616.

Maw, B.W.; D.A.; Smittle and B.G. Mullinix (1997a). Artificially curing sweet onions. Applied-Engineering-in-Agriculture. 13: 4, 517-520.

Maw, B.W.; E.W. Tollner and B.G. Mullinix (1997b). Factors influencing the curing of sweet onions. ASAE Annual International Meeting, Minneapolis, Minnesota, USA, Paper No. 971021, 17 pp.

Ministry of Agricultural and Land Reclamation. (2008). Study of important indicators of the agricultural Statistics. Arab Republic of Egypt. Ministry of Agricultural and Land Reclamation Economic Affairs Sector. Vol.(2), August 2008 ,pp.191.

Ministry of Economics and Foreign Trade. General Organization for Exports and Imports Control. (1992). Quality Specifications for Exported Fresh Fruits and Vegetables - The Central Administration for Exports. Pp. 59- 62.

Pandey, U. B.; S.R. Bhonde; and V.K. Mishra (1993). Shelf life of kharif onion as influenced by curing and storage with foliage. Newsletter Associated Agricultural Development Foundation. 13: 1, 5-8.

Sanguansri, P; and I.V. Gould(1992). Onions: artificial curing system and objective quality evaluation. Agricultural engineering conference 1990. Proceedings of a conference held in Toowoomba, Australia, 1114 November 1990. (333-337).

Wilson, L. G.; and E. A. Estes (1994). Postharvest cooling and handling of onions - North Carolina Cooperative Extension Service. North Carolina State Univ., USA.

Yang, Y. J. and K. A. Lee (2000). Effect of postharvest curing on respiration and quality in onion bulbs during cold storage. American HortScience 31: 723-890. 


\section{الملخص العربي \\ بعض العوامل المؤثرة على التسميط الصناعي للأبصال وأثرها علي قابليتها للتخزين البين}

د.ماجدة محمد عبد الرحمن* د. محمد طه عبيد*

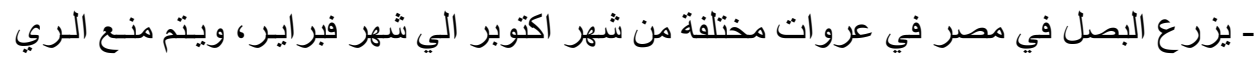

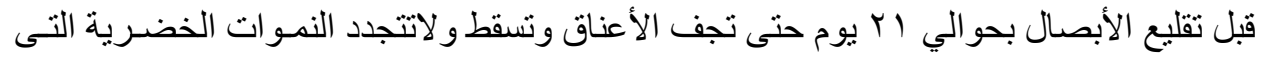

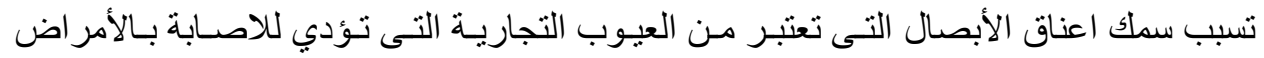

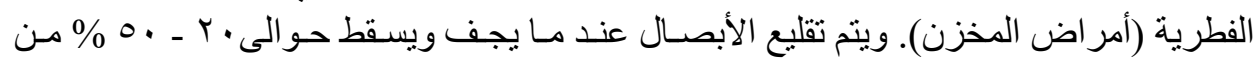
عروش الأبصال.

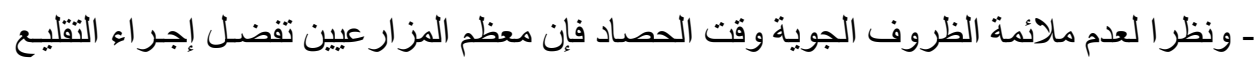

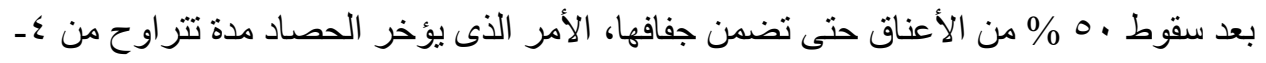

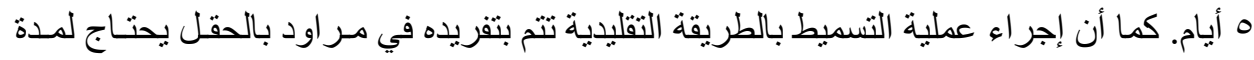

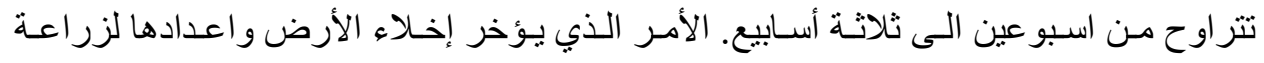

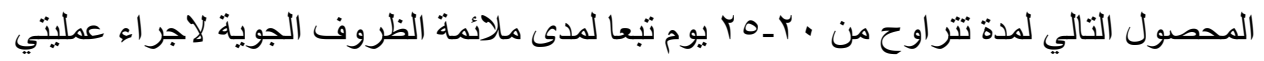
الحصاد و التسميط.

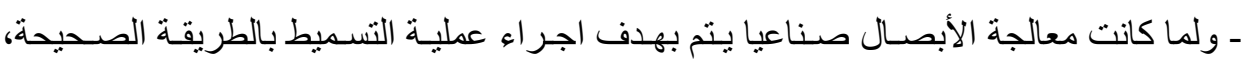

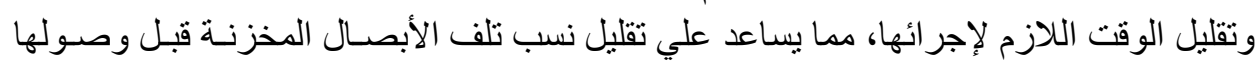

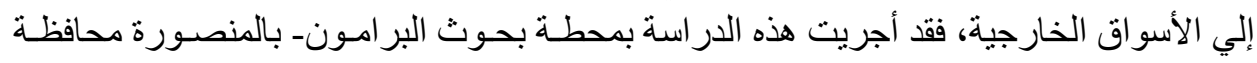

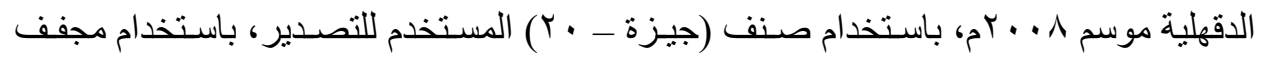
صناعي يعمل بطريقة السريان الجبري للهو الهواء المسخن.

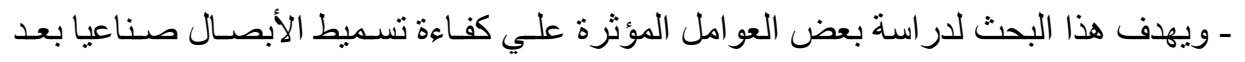

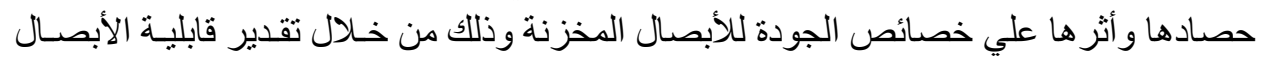

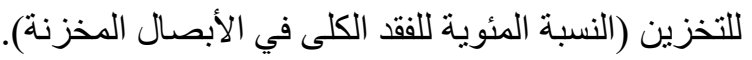

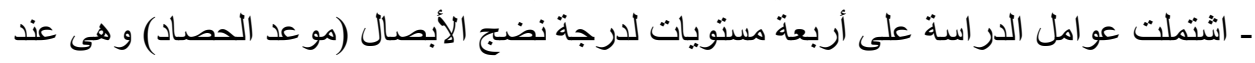

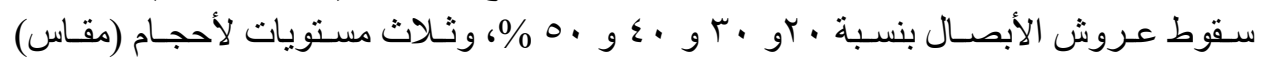

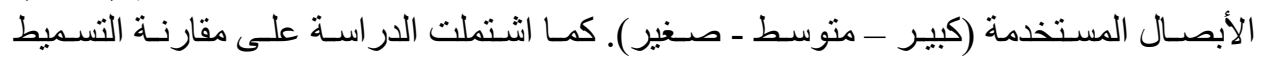

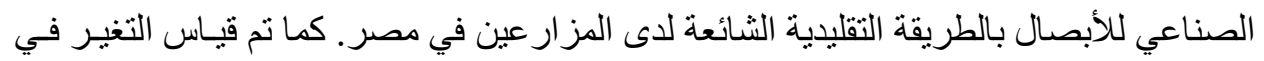

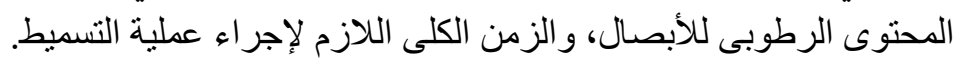

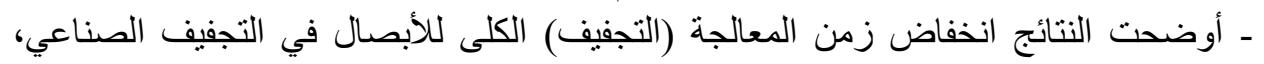

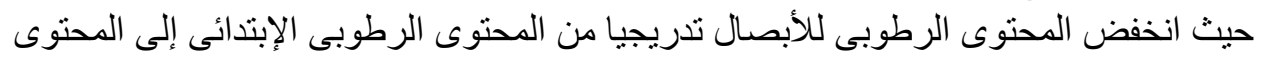

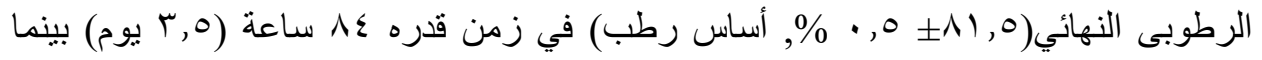

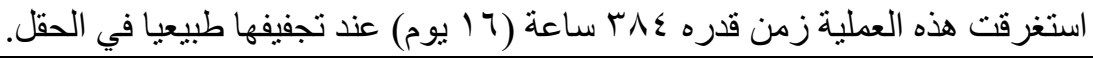
*باحث أول بمعهد بحوث الهندسة الزر اعية ـ الدقي - جيزة. 
- إنخفض الزمن الكلى اللازم لتجفيف الأبصال الكبيرة الحجم صناعيا عند مقارنته بطريقة

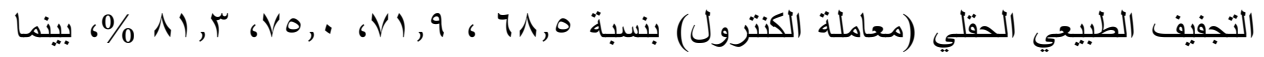

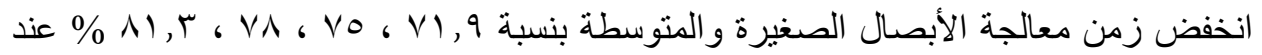

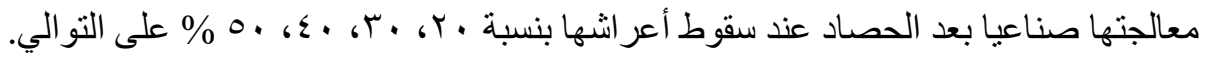

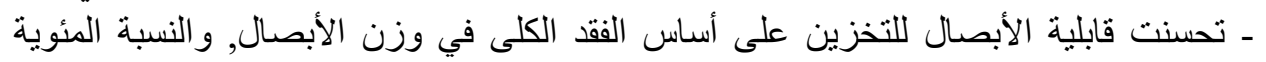

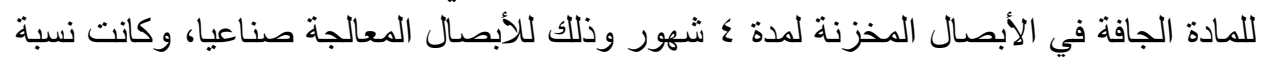

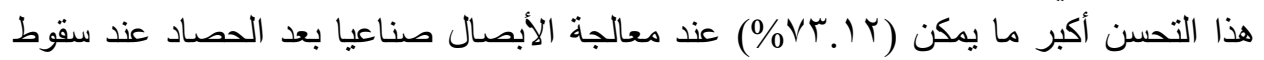

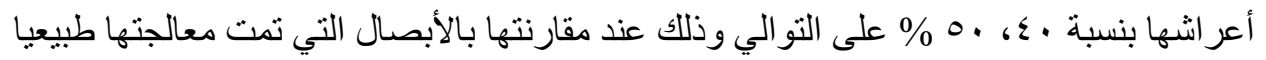

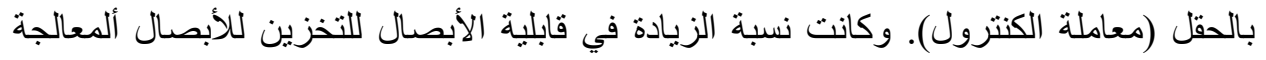

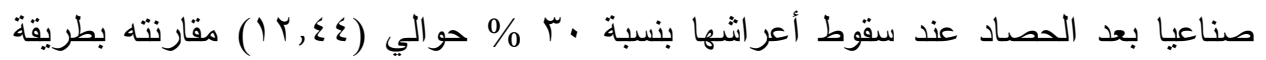
التجفيف الطبيعي الحقلي (معاملة الكنترول).

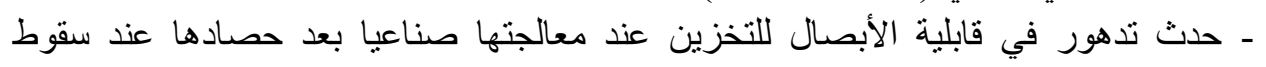

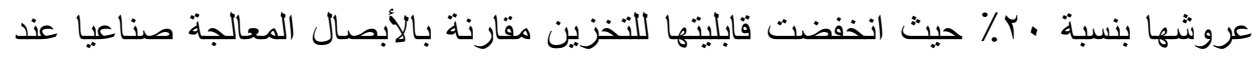

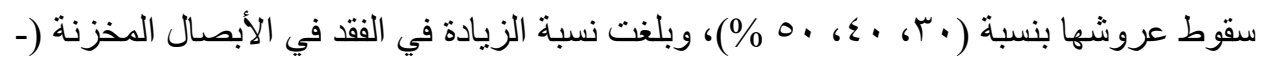

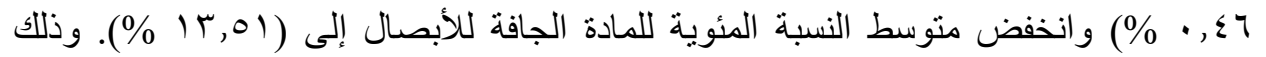
بالمقارنة بالأبصال ألتى تمت معالجنها حقليا. 